\title{
A PHARMACOGNOSTIC AND PHARMACOLOGICAL REVIEW ON CHROMOLAENA ODORATA (SIAM WEED)
}

\author{
VANITA KANASE*, SANA SHAIKH \\ Department of Pharmacology, Oriental College of Pharmacy, Sanpada, Navi Mumbai, Maharashtra, India. Email: vanita.kanase@gmail.com \\ Received: 24 April 2018, Revised and Accepted: 14 May 2018
}

\begin{abstract}
Chromolaena odorata is commonly known as Siam weed which belongs to sunflower family Asteraceae. C. odorata is an important medicinal plant which can be easily found in tropical Asia, West Africa, and parts of Australia. It is native to the America, and found in Florida and Texas in the United States, throughout Mexico and the Caribbean to South America. The medicinal usage of $C$. odorata has been reported in the traditional systems of medicine such as Ayurveda, Siddha, and Unani. It has wide variety of ethanomedicinal and pharmacological properties. The young leaves are crushed, and the resulting liquid can be used to treat skin wounds. The leaves extract is used by the kani tribals of Kouthalai in Tirunelveli hills to cure skin diseases, poison bites, wounds, and rheumatism. Following various folk claims for the ailment of various diseases, efforts have been made by the researchers to verify the efficacy of this weed through scientific biological screenings. A study of the literature revealed some notable pharmacological activities of the shrub such as anthelmintic, antimalarial, analgesic, anti-inflammatory, antipyretic, antispasmodic, antioxidant, antigonorrheal, antimycobacterial, insecticidal, fungicidal, wound healing, diuretic, blood coagulation, and antibacterial. The current review is created with an intent to focus on the numerous ethnobotanical and traditional uses as well as the phytochemical and pharmacological reports on $C$. odorata.
\end{abstract}

Keywords: Antioxidant, Chromolaena odorata, Healing property, Plant, Traditional medicine, Wound.

(C) 2018 The Authors. Published by Innovare Academic Sciences Pvt Ltd. This is an open access article under the CC BY license (http://creativecommons. org/licenses/by/4. 0/) DOI: http://dx.doi.org/10.22159/ajpcr.2018.v11i10.26863

\section{INTRODUCTION}

Currently, natural products are a significant source of new compounds, leading to the synthesis of drugs in all major disease areas. They epitomize a pool of structures that have been optimized by evolution to interact with different molecules such as proteins and other molecules [1]. The starting materials for about one-half of the medicines we use today come from natural sources. The future of higher plants as sources of medicinal agents for use in investigation, prevention, cure, and treatment of diseases is also very promising [2]. During the past decade, the traditional systems of medicine have become progressively popular keeping in mind their safety. Natural products proved to be an important source of lead compounds in the development of new drugs [3]. Natural products have provided some of the important lifesaving drugs used in the armamentarium of modern medicine. However, among the estimated 250,000-400,000 plant species, only 6\% have been studied for biological activity and $15 \%$ have been examined phytochemically [4]. Phytochemicals may protect human from a variety of diseases. Phytochemicals are non-nutritive plant compounds, which have protective, curative, or disease preventive properties. Plants produce these chemicals to protect themselves, but recent research demonstrates that many phytochemicals can protect humans against diseases. There are many phytochemicals in fruits and herbs and each works differently [5]. This illustrates the need for planned activity guided phytopharmacological evaluation of herbal drugs. This article aims to provide an overview of the chemical constituents present in various parts of Chromolaena odorata and their ethnobotanical and pharmacological actions. It has been claimed in Ayurveda that C. odorata possesses proven medicinal properties and is the ingredient of many formulations.

\section{HABITAT AND DISTRIBUTION}

The family Asteraceae comprises over 165 species that are distributed across tropical and subtropical regions. The tropical and subtropical regions are the best for growth of Siam weed, and though not tolerant of cold climate it can be still found at altitudes up to $1000 \mathrm{~m}$. Even though Siam weed grows on most soil types, it preferred well-drained soils in full sun. It has a viable benefit over other plants in weathers with distinct wet and dry seasons because it endures fires and grows back vigorously following rain. It is one of the invasive, fast-growing plants, and thrives in disturbed areas such as meadows, farms, clearings, roadsides, and shores, particularly those in well-lit sites. Siam weed is misleadingly named as it is actually a native of Central and Northern South America, from Mexico to Brazil. Although first introduced into India as an ornamental, it has quickly spread throughout its current range [6].

\section{MORPHOLOGY}

C. odorata or Siam weed has a minimum 10-year life span. It is a rapidly growing perennial herb. Siam weed is a big bushy herb or subshrub with long rambling but not having twisted branches. In open areas, it spreads into scrambled and compressed thickets up to 2-meter high. The main stem consists of many paired branches. The base of the plant becomes hard and woody. Branch tips are often soft and green. The arrowheadshaped leaves have three characteristic veins in a "pitchfork" pattern. Leaves are 4-10 cm long and 1-5 cm wide. They breed in contradictory pairs alongside the stems and branches. The term "Odorata" suggests that the leaves release a pungent, aromatic odor when crushed. Light pink-mauve or white tubular flowers, $10 \mathrm{~mm}$ long, are found at the ends of branches in clusters of 10-35. The dark-colored seeds are 4-5 mm long, narrow, and oblong, with a parachute of white hairs which turn brown as the seed dries. 80,000-90,000 seeds are produced per plant. Siam weed is native to tropical America but is now acclimatized throughout the tropics [7]. Habit (a), flowers (b), leaves (c), and seeds (d) of Chromolaena odorata are shown in Fig. 1.

Taxonomical classification [8]

Kingdom: Plantae

Subkingdom: Viridiplantae

Infrakingdom: Streptophyta

Superdivision: Embryophyta

Division: Tracheophyta

Subdivision: Spermatophytina

Class: Magnoliopsida 
Superorder: Asteranae

Order: Asterales

Family: Asteraceae

Genus: Chromolaena

Species: C. odorata.

\section{Nomenclature}

C. odorata aka Eupatorium odoratum is a weedy herb native of Central and South America, which has spread throughout the tropical and subtropical areas $[9,10]$. It was first introduced to Southeast Asia in the 1920s and Africa in around 1940 as a plantation cover crop and has ever since spread worldwide (Table 1) [11,12]

\section{Phytoconstituents}

The dried leaf of $C$. odorata contained carbohydrate (31\%), crude protein $(18 \%)$, fiber $(15 \%)$, crude fat $(11 \%)$, ash $(11 \%)$, and moisture (15\%) [14]. Its active phytochemical substances are as follows:

1. Essential oils [15-17].

2. Flavonoid aglycones (flavanones, flavonols, and flavones) including naringenin, kaempferol, quercetin, acacetin, chalcones, eupatilin, luteolin, quercetagetin, and sinensetin [18-21].

3. Terpenes and terpenoids [22].

4. Saponins and tannins [14].

Table 1: Names used worldwide of $C$. odorata are as follows $[12,13]$

\begin{tabular}{|c|c|}
\hline Language & Vernacular name \\
\hline English & $\begin{array}{l}\text { Devil weed, Christmas bush, Jack in the bush, } \\
\text { communist weed, Siam weed }\end{array}$ \\
\hline Hindi & Bagh dhoka, tivra gandha \\
\hline French & Herbe du Laos \\
\hline German & Siam kraut \\
\hline Guam & Kesengesil \\
\hline African & $\begin{array}{l}\text { Sekou toure, acheampong, jabinde, matapa, } \\
\text { mighbe }\end{array}$ \\
\hline Indonesian & Rumput belalang, rumput putih, rumput golkar \\
\hline Malayalam & $\begin{array}{l}\text { Pokok kapal terbang, rumput jepun, rumput } \\
\text { Siam }\end{array}$ \\
\hline Sanskrit & Ropani, seekhrasarpi \\
\hline Spanish & Cariaquillo Santa Maria \\
\hline Tagalog & Agonoi, hagonoy, huluhagonoi \\
\hline Thai & Sab suea \\
\hline Vietnamese & Co hoi \\
\hline
\end{tabular}

C. odorata: Chromolaena odorata

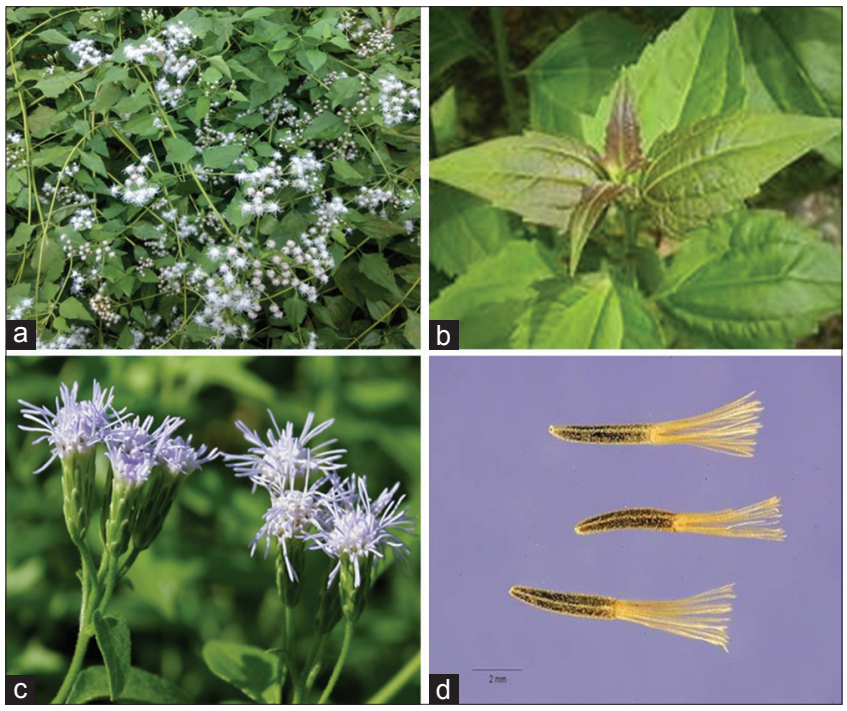

Fig. 1: Habit (a), flowers (b), leaves (c), and seeds (d) of Chromolaena odorato
Some major phytoconstituents are shown in Fig. 2.

5. Alkaloids including pyrrolizidine [23-25].

6. Phytoprostane compound including chromomoric acid [26].

7. Phenolic acids including ferulic acid and protocatechuic acid [27]

\section{Traditional uses}

From literature review regarding the traditional uses, phytochemical properties of C. odorata are antibacterial [28-31], anticancer [32], anticonvulsant [33], antidiabetic [34-36], antidiarrheal [37,38], antifungal [39,40], anti-inflammatory [41-43], antioxidant [44-47], and antiparasitic [24], hemostatic and wound healing [47,48], and hepatoprotective activities $[49,50]$.

\section{PHARMACOLOGICAL ACTIVITIES}

C. odorata is found to be a highly efficient medicinal herb according to the traditional and widespread medicinal systems. The same is proved by its pharmacological evaluation performed by scientific community across the world.

\section{Anti-inflammatory, analgesic, and antipyretic activity}

C. odorata is traditionally usage in the treatment of rheumatic fever and similar conditions. This is evident for anti-inflammatory, analgesic, and antipyretic activities of the $C$. odorata. In the study conducted by Umukoro et al., 2006, for pharmacological evaluation of the drug extract in different animal experimental models which comprise carrageenan paw edema and cotton pellet granuloma for determination of anti-inflammatory activities, hot plate, and formalin paw licking tests for determination of analgesic activities, and Brewer's yeast induced pyrexia for determination of antipyretic tests.

The result shows that the extract produced dose-dependent antiinflammatory, analgesic, and antipyretic activities. Other studies have shown that the anti-inflammatory activity may be attributed because of the presence of flavonoids in the extract $[51,52]$.

\section{Antimicrobial activity}

The $C$. odorata plant considered and used traditionally for its antimicrobial action, thus the antimicrobial activity of was evaluated in multiple experiments by various researchers.

This antimicrobial activity plays a major role in the aspect of wound healing power, which is expressed by the shrub. The $C$. odorata dichloromethanolic and ethanolic crude extracts have been assessed against 22 strains of microorganisms consisting of various Grampositive and Gram-negative bacteria and yeasts.

Pisutthanan et al., 2005, presented that all crude extracts have shown activity, mainly against Gram-positive bacteria. The extracts have also shown modest activity against Mycobacterium tuberculosis [52]. The dichloromethane-water extract of the plant exhibited significant antiherpes simplex virus-1 and antimalarial activity [52]. Ling et al. found out that the activity is particularly stronger against staphylococci [53]. The extract also displayed appreciable antifungal activity [54]. Thoden et al., 2007, have also demonstrated profound nematicidal activity of the herb [24].

\section{Antioxidant}

The profound antioxidant action of the plant is the basis of its external application of $C$. odorata [51,53]. Phan et al., 2001, assessed the plant extract for its antioxidant effects using purified fractions on cultured fibroblasts and keratinocytes. This experiment was evaluated by investigation with the help of colorimetric and lactate hydrogenase release assay.

The results of this test indicated that the phenolic acids, which are present in the extract such as p-coumaric, ferulic, protocatechuic, p-hydroxybenzoic, and vanillic acids, as well as complex mixtures of hydrophobic flavonoid aglycones such as flavones, flavanones, chalcones, and flavonols, were principal and potent antioxidants [27]. 


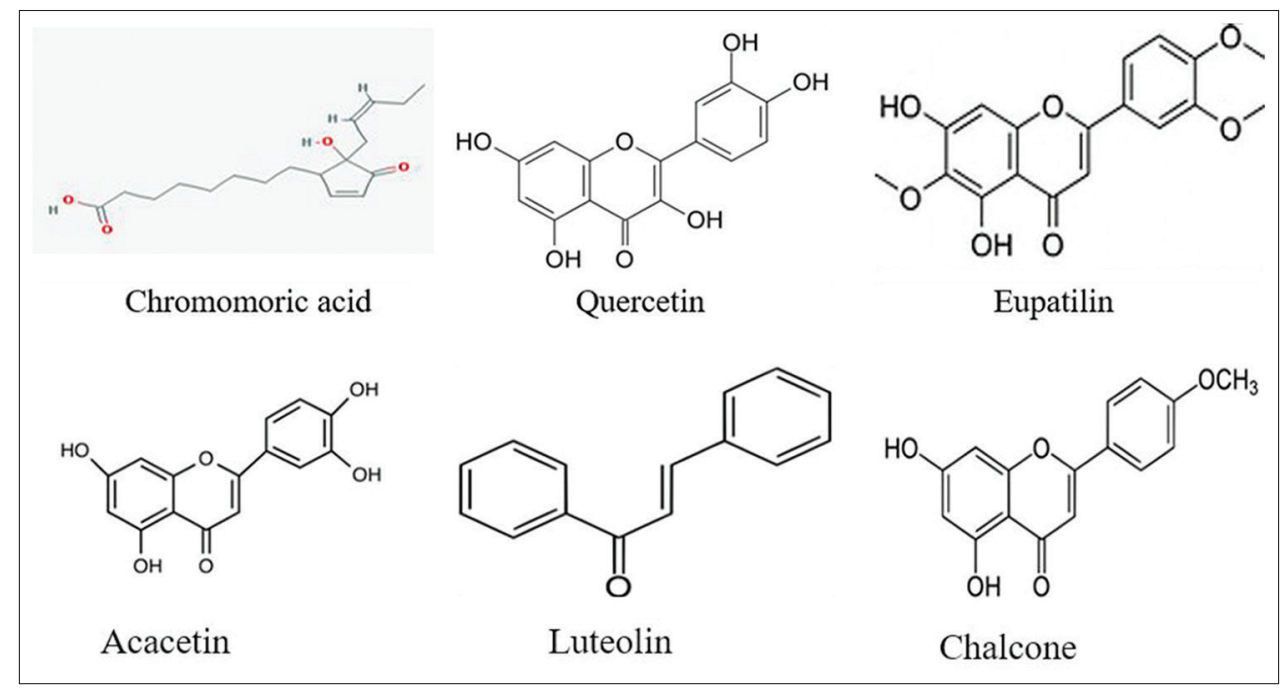

Fig. 2: Various phytoconstituents of Chromolaena odorata

The nitric oxide scavenging activity of the $C$. odorata extract was demonstrated by Alisi et al., 2008, in which it was quantitatively determined by the total phenolic content which shows that the extract contains an appreciable quantity of the phenolic compounds and these compounds might be responsible for the antioxidant potential of the extract [55]

\section{Cardiovascular effects}

The studies conducted by Umukoro et al., 2006, on the cardiovascular effects of the $C$. odorata extract exhibited its significant membrane stabilizing activity against hemolysis as well as PAF receptor-binding inhibiting property [51].

\section{Cytoprotective}

An experiment conducted by Nurjannah et al., 2006, in rats proved their efficacy as an antiulcer agent when used orally [56]. For this research, $C$. odorata extract was given in combination with honey for its use in the treatment of stomach ulcer lacerations. Cytotoxic studies of the $C$. odorata extract were also carried out. These studies demonstrated the presence of number of compounds in the extract such as acacetin (5, 7-dihydroxy4'-methoxy flavone) and luteolin (5, 7, 3', 4'-tetrahydroxyflavone). These compounds also expressed for their significant activity against human small cell lung cancer and human breast cancer

\section{Wound healing}

The most established and discussed aspect of Chromolaena is its role in wound healing. Ayyanar et al., 2009, established that extracts from the leaves of $C$. odorata have been shown to be useful for the treatment of wounds. In traditional usage, the leaf is ground into a paste and is applied topically on affected places to heal wounds [57]. Raina et al., 2008 , showed that the aqueous extract and the decoction from leaves of this plant have been used throughout Vietnam for the treatment of soft tissue wounds and burns for decades. A product named EUPOLIN made from Chromolaena has already been licensed for use in Vietnam for soft tissue burns and injuries [58,59].

\section{CONCLUSION}

C. odorata is very useful habit for treating various types of diseases. Various studies have demonstrated that $C$. odorata possesses antiinflammatory, analgesic, antipyretic, antimicrobial, cardiovascular effects, cytoprotective, wound healing, nematicidal, and antimalarial activity. The chemical constituents such as phenolic acids, flavonoids, and other important chemical constituents are responsible for these activities. Review of the literature concluded that $C$. odorata is considered to be a useful herbal medicinal plant.

\section{ACKNOWLEDGMENT}

We are grateful to our Principal Dr. (Mrs.) Sudha Rathod, Prof. Imtiyaz Ansari, and Dr. Sayyed Mateeen for their guidance and support as well as to Pharmacology Dept., Oriental College of Pharmacy, Navi Mumbai.

\section{AUTHOR'S CONTRIBUTION}

We declare that this work was done by the authors named in this article and all liabilities pertaining to claims relating to the content of this article will be borne by the authors. Miss Sana Shaikh collected the data and analyzed the data. Dr. (Mrs.) Vanita Kanase proofread the whole manuscript, and suggested the necessary changes, and helps in designing manuscript.

\section{CONFLICTS OF INTEREST}

The authors declare that there are no conflicts of interest regarding the publication of this paper.

\section{REFERENCES}

1. Dirsch V. Faculty of Life Sciences. Wien: Universitat Wien; 2006.

2. Setzer N. Natural Products Drug Discovery. Huntsville: Department of Chemistry, University of Alabama in Huntsville; 1999.

3. Tilak R, Kumar P, Rathee R, Dubey KK. Screening of some medicinal plants for their antimicrobial activities. Int J Pharm Pharm Sci 2016;8:202-6.

4. Chaudhary PH, Khadabadi S. Bombax ceiba Linn.: Pharmacognosy, ethnobotany and phyto-pharmacology pharmacognosy. Communications 2012. DOI: $10.5530 / \mathrm{pc} .2012 .3 .2$.

5. Pathak D, Alam K, Rohilla H, Agarwal A. Phytochemical investigation of Boerhavia diffusa and andrographis Paniculata: A comparative study. Int J Pharm Pharm Sci 2012;4 Suppl 4:250-1.

6. Gunasekera L. Invasive Plants: A Guide to the Identification of the Most Invasive Plants of Sri Lanka, Colombo; 2009. p. 116-7. Siam Weed or Chromolaena (Chromolaena odorata) Weed Management Guide. Available from: http://www.environment.gov.au/biodiversity/ invasive/weeds/publications/guidelines/alert/pubs/c-odorata. pdfandPierreBinggeli"Chromolaenaodorata(L.)King\&Robinson (Asteraceae)",1997.

7. King RM, Rob H. Chromolaena odorata (L.) Germplasm Resources Information Network (GRIN). Agricultural Research Service (ARS), United States Department of Agriculture (USDA). Available from: http://self.gutenberg.org/articles/eng/chromolaena odorata. [Last retrieved on $2017 \mathrm{Jul} 15$ ]

8. Integrated Taxonomic Information System (ITIS). Chromolaena odorata (L.) R.M. King and H. Rob. Taxonomic Serial No.: 37034, Geological Survey, VA, USA; 2016.

9. Gautier L. Taxonomy and distribution of a tropical weed Chromolaena 
odorata (L.). R. King and H. Robinson. Candollea 1992;47:645-62.

10. Omokhua AG, McGaw LJ, Finnie JF, Van Staden J. Chromolaena odorata (L.). R.M. King \& H. Rob. (Asteraceae) in sub-Saharan Africa: A synthesis and review of its medicinal potential. J Ethnopharmacol 2016;183:112-22.

11. Rouw A. The invasion of Chromolaena odorata and competition with the native flora in a rain forest zone, South-west Côte d'Ivoire. J Biogeogr 1991;18:13-23.

12. Kouamé PB, Jacques C, Bedi G, Silvestre V, Loquet D, Barillé-Nion S, et al. Phytochemicals isolated from leaves of Chromolaena odorata: Impact on viability and clonogenicity of cancer cell lines. Phytother Res 2013;27:835-40.

13. Vaisakh MN, Pandey A. The invasive weed with healing properties: A review on Chromolaena odorata. Int J Pharm Sci Res 2012;3:80-3.

14. Anyasor GN, Aina DA, Olushola M, Aniyikawe AF. Phytochemical constituents, proximate analysis, antioxidants, anti-bacterial and wound healing properties of leaf extracts of Chromolaena odorata. Ann Biol Res 2011;2:441-51.

15. Bamba D, Bessière JM, Marion C, Pélissier Y, Fourasté I. Essential oil of Eupatorium odoratum. Planta Med 1993;59:184-5.

16. Bouda H, Tapondjou LA, Fontem DA, Gumedzoe MY. Effect of essential oils from leaves of Ageratum conyzoides, Lantana camara and Chromolaena odorata on the mortality of Sitophilus zeamais (Coleoptera, Curculionidae). J Stored Prod Res 2001;37:103-9.

17. Pisutthanan N, Liawruangrath $B$, Liawruangrath $S$, Baramee A, Apisariyakul A, Korth J, et al. Constituents of the essential oil from aerial parts of Chromolaena odorata from Thailand. Nat Prod Res 2006;20:636-40.

18. Barua RN, Sharma RP, Thyagarajan G, Hertz W. Flavonoids of Chromolaena odorata. Phytochemistry 1978;17:1807-8.

19. Wollenweber E, Dorr M, Muniappan R. Exudate flavonoids in a tropical weed Chromolaena odorata (L.). R.M. King and H. Robinson. Biochem Syst Ecol 1995;23:873-4.

20. Wollenweber E, Roitman JN. A novelmethy ether of quercetagetin from Chromolaena odorata leaf exudate. Biochem Syst Ecol 1996;24:479-80.

21. Suksamrarn A, Chotipong A, Suavansri T, Boongird S, Timsuksai P, Vimuttipong $\mathrm{S}$, et al. Antimycobacterial activity and cytotoxicity of flavonoids from the flowers of Chromolaena odorata. Arch Pharm Res 2004;27:507-11.

22. Wafo P, Kamdem RS, Ali Z, Anjum S, Begum A, Oluyemisi OO, et al. Kaurane-type diterpenoids from Chromoleana odorata their X-ray diffraction studies and potent a-glucosidase inhibition of 16-kauren-19oic acid. Fitoterapia 2011;82:642-6.

23. Biller A, Boppre M, Witte L, Hartmann T. Pyrrolizidine alkaloids in Chromolaena odorata. Chemical and chemoecological aspects. Phytochemistry 1994;35:615-9

24. Thoden TC, Boppre M, Hallmann J. Pyrrolizidine alkaloids of Chromolaena odorata act as nematicidal agents and reduce infection of lettuce roots by Meloidogyne incognita. Nematology 2007;9:343-9.

25. Yakubu MT. Effect of a 60-day oral gavage of a crude alkaloid extract from Chromolaena odorata leaves on hormonal and spermatogenic indices of male rats. J Androl 2012;33:1199-207.

26. Heiss EH, Tran TV, Zimmermann K, Schwaiger S, Vouk C, Mayerhofer B, et al. Identification of chromomoric acid C-I as an Nrf2 activator in Chromolaena odorata. J Nat Prod 2014;77:503-8.

27. Phan TT, Wang L, See P, Grayer RJ, Chan SY, Lee ST. Phenolic compounds of Chromolaena odorata protect cultured skin cells from oxidative damage: Implication for cutaneous wound healing. Biol Pharm Bull 2001;24:1373-9.

28. Irobi ON. Activities of Chromolaena odorata (Compositae) leaf extract against Pseudomonas aeruginosa and Streptococcus faecalis. J Ethnopharmacol 1992;37:81-3.

29. Johari SA, Kiong LS, Mohtar M, Isa MM, Man S, Mustafa S, et al. Efflux inhibitory activity of flavonoids from Chromolaena odorata against selected methicillin-resistant Staphylococcus aureus (MRSA) isolates. Afr J Microbiol Res 2012;6:5631-5.

30. Kigigha LT, Zige DV. Activity of Chromolaena odorata on enteric and superficial etiologic bacterial agents. Am J Res Commun 2013;1:266-76.

31. Stanley MC, Ifeanyi OE, Nwakaego CC, Esther IO. Antimicrobial effects of Chromolaena odorata on some human pathogens. Int J Curr Microbiol Appl Sci 2014;3:1006-12.

32. Adedapo AA, Oyagbemi AA, Fagbohun OA, Omobowale TO, Yakubu MA. Evaluation of the anticancer properties of the methanol leaf extract of Chromolaena odorata on HT29 lung cancer cell line. FASEB J 2016;30 Suppl: 1193.6.

33. Amazu LU, Omoregie P, Ajugwo AO, Ifezulike CC, Azikiwe CC.
Anticonvulsant potency of the leaf extract of Chromolaena odorata in rats. Unique Res J Med Med Sci 2013;1:64-9.

34. Onkaramurthy M, Veerapur VP, Thippeswamy BS, Reddy TN, Rayappa H, Badami S. Anti-diabetic and anti-cataract effects of Chromolaena odorata Linn. Instreptozotocin-induced diabetic rats. J Ethnopharmacol 2013;145:363-72.

35. Ijioma SN, Okafor AI, Ndukuba PI, Nwankwo AA, Akomas SC. Hypoglycemic, hematologic and lipid profile effects of Chromolaena odorata ethanol leaf extract in alloxan induced diabetic rats. Ann Biol Sci 2014;2:27-32.

36. Uhegbu FO, Imo $\mathrm{C}$, Onwuegbuchulam $\mathrm{CH}$. Lipid lowering, hypoglycemic and antioxidant activities of Chromolaena odorata (L) and Ageratum conyzoides (L) ethanolic leaf extracts in albino rats. J Med Plants Stud 2016;4:155-9.

37. Atindehou M, Lagnika L, Guérold B, Strub JM, Zhao M, Dorsselaer AV, et al. Isolation and identification of two anti-bacterial agents from Chromolaena odorata L. active against four diarrheal strains. Adv Microbiol 2013;3:115-21.

38. Aba PE, Joshua PE, Ezeonugu FC, Ezeja MI, Omoja VU, Umeakuana PU. Possible anti-diarrhoeal potential of ethanol leaf extract of Chromolaena odorata in castor oil-induced rats. J Complement Integr Med 2015;12:301-6.

39. Ngono NA, Etame RE, Ndifor F, Biyiti L, Amvam ZP, Bouchet P. Antifungal activity of Chromolaena odorata (L.). King and Robinson (Asteraceae) of Cameroon. Chemotherapy 2006;52:103-6.

40. Naidoo KK, Coopoosamy RM, Naidoo G. Screening of Chromolaena odorata (L.) King and Robinson for anti-bacterial and anti-fungal properties. J Med Plant Res 2011;5:4859-62.

41. Owoyele VB, Adediji JO, Soladoye AO. Anti-inflammatory activity of aqueous leaf extract of Chromolaena odorata. Inflammopharmacology 2005; $13: 479-84$.

42. Hanh TT, Hang DT, Minh CV, Dat NT. Anti-inflammatory effects of fatty acids isolated from Chromolaena odorata. Asian Pac J Trop Med 2011;4:760-3.

43. Pandith H, Zhang X, Thongpraditchote S, Wongkrajang Y, Gritsanapan W, Baek SJ. Effect of Siam weed extract and its bioactive component scutellareintetramethyl ether on anti-inflammatory activity through NF- $\kappa$ B pathway. J Ethnopharmacol 2013;147:434-41.

44. Rao KS, Chaudhury PK, Pradhan A. Evaluation of anti-oxidant activities and total phenolic content of Chromolaena odorata. Food Chem Toxicol 2010;48:729-32.

45. Vijayaraghavan K, Ali SM, Maruthi R. Studies on phytochemical screening and antioxidant activity of Chromolaena odorata and Annona squamosal. Int J Innov Res Sci Eng Technol 2013;2:7315-21.

46. Boudjeko T, Megnekou R, Woguia AL, Kegne FM, Ngomoyogoli JE, Tchapoum $\mathrm{CD}$, et al. Antioxidant and immunomodulatory properties of polysaccharides from Allanblackia floribunda Oliv stem bark and Chromolaena odorata (L.). King and H.E. Robins leaves. BMC Res Notes 2015;8:759.

47. Akah PA. Mechanism of hemostatic activity of Eupatorium odoratum. Int J Crude Drug Res 1990;28:253-6.

48. Pandith H, Zhang X, Liggett J, Min KW, Gritsanapan W, Baek SJ. Hemostatic and wound healing properties of Chromolaena odorata leaf extract. ISRN Dermatol 2013;2013. Article ID: 168269, 8 Pages.

49. Alisi CS, Onyeze GO, Ojako OA, Osuagwu CG. Evaluation of the protective potential of Chromolaena odorata Linn. Extract on carbon tetrachloride-induced oxidative liver damage. Int J Biochem Res Rev 2011;1:69-81.

50. Asomugha RN, Okafor PN, Ijeh II, Orisakwe OE, Asomugha AL. Hepatic effects of aqueous extract of Chromolaena odorata in male Wistar albino rats. Pharmacol Online 2014;1:127-36.

51. Umukoro S, Ashorobi RB. Evaluation of the anti-inflammatory and membrane stabilizing effects of Eupatorium odoratum. Int J Pharmacol 2006;2:509-12.

52. Pisutthanan N, Liawruangrath S, Bremner JB, Liawruangrath B. Chemical constituents and biological activities of Chromolaena odorata. Chiang Mai J Sci 2005;32:139-48.

53. Ling SK, Azah MA, Mastura M, Khoo MG, Husni SS, Salbiah M, et al. Chemical Constituents and Therapeutic Potential of the Leaf Extract from Chromolaena odorata (L.) King and Robinson. 52109 Kepong, Selangor Darul Ehsan: Forest Research Institute Malaysia (FRIM).

54. Owolabi MS, Ogundajo A, Yusuf KO, Lajide L, Villanueva HE, Tuten JA, et al. Chemical composition and bioactivity of the essential oil of Chromolaena odorata from Nigeria. Rec Nat Prod 2010;4:72-8.

55. Alisi CS, Onyeze GO. Nitric oxide scavenging ability of ethyl acetate fraction of methanolic leaf extracts of Chromolaena odorata (Linn.). Afr J Biochem Res 2008;2:145-50. 
56. Jannah MH, Mahmood AA, Sidik K, Salmah I. Cytoprotective effects of honey in combination with aqueous and ethanol extracts from Chromolaena odorata L (Eupatorium odoratum) in rats. Jummec 2006;9:8.

57. Ayyanar M, Ignacimuthu S. Herbal medicines for wound healing among tribal people in Southern India: Ethnobotanical and Scientific evidences. Int J Appl Res Nat Prod 2009;2:29-42.
58. Raina R, Parwez S, Verma PK, Pankaj NK. Medicinal plants and their role in wound healing. Online Vet J 2008;3:21.

59. Phan TT, Hughes MA, Cherry GW. Enhanced proliferation of fibroblasts and endothelial cells treated with an extract of the leaves of Chromolaena odorata (Eupolin), a herbal remedy for treating wounds. Plastic Reconstr Surg 1998;101:756-5. 